\title{
CONSTITUINTE E DEMOCRATIZAÇÃO NO BRASIL: $O$ IMPACTO DAS MUDANÇAS DO SISTEMA INTERNACIONAL
}

Ademar Seabra da Cruz Júnior

Em entrevista à Veja, Raymundo Faoro preconizava, um tanto categoricamente, que "[...] todas as mudanças importantes ocorridas na história do Brasil resultaram de alterações na ordem internacional. Foi assim com a própria Independência" (Faoro, 1976). Nessa entrevista, o autor de Os donos do poder buscava assinalar que mudanças de rumo marcantes na história do país - tais como, além da Independência, a Revolução de 1930, a redemocratização incompleta de 1946 e a intervenção militar de 1964 - deitavam raízes mais profundas em aspectos sistêmicos da ordem internacional na qual se desenrolavam. No caso de 1964, era evidente que a investida dos tanques sobre a Guanabara, sob o comando do general Olympio Mourão Filho, e a truculenta declaração de vacância da Presidência da República, em primeiro de abril daquele ano (com o presidente João Goulart ainda em território nacional), constituíam, em grande medida, epifenômenos dramáticos do impacto da Guerra Fria sobre a política brasileira.

A leitura de Faoro longe está de constituir uma interpretação isolada da política contemporânea do Brasil. A 
análise das transformações sociais e políticas que culminaram na plena democratização nos anos de 1990 indica que essas transformações guardam estreita relação com a crise do modelo desenvolvimentista da era de substituição de importações; tal crise está correlacionada, por sua vez, com mudanças marcantes no padrão de acumulação do sistema capitalista internacional a partir da quebra do padrão-ouro, em 1971, e com a transformação do perfil produtivo da Europa, EUA e dos países de industrialização recente, nos anos de 1970 e de 1980. Durante os anos de 1970, o Brasil passa gradualmente da condição de market maker do mercado mundial de matérias-primas (chegando a concentrar 2,2\% do fluxo mundial de comércio em 1952) a uma participação inferior a 1\%, ainda antes da crise econômica de 1982 (Abreu, 2002, p. 32). Sallum Júnior (1996) também sustenta que fatores externos desempenharam papel decisivo na precipitação, aceleração e superação da crise de 218 Estado que assolou o Brasil nos anos de 1980¹.

A análise neoinstitucionalista das crises do Estado, do regime e do governo da primeira metade dos anos de 1980 enfrentaria dificuldades, dessa forma, ao localizar os fatores desencadeantes dessas crises em movimentos eminentemente endógenos do cenário político-econômico nacional. Esses três grandes movimentos, distintos, mas inter-relacionados e interdependentes (ao fim do Estado desenvolvimentista e do regime de substituição de importações se seguiram a abertura comercial com nova política industrial;

\footnotetext{
${ }^{1}$ Sallum Júnior (1996, pp. 168-9) sintetiza da seguinte maneira essa dependência da economia brasileira do cenário externo: "[...] os processos de transnacionalização foram adquirindo uma base tecnológica que tornou mesquinho o patamar de produtividade alcançado pela indústria brasileira. Enquanto o Brasil completava - a duras penas e aumentando extraordinariamente sua dependência em relação ao mercado financeiro internacional - seu processo de industrialização dentro do padrão tecnológico pertinente à segunda revolução industrial, as grandes corporações dos países centrais avançavam dentro de um novo padrão, o da chamada terceira revolução industrial, no qual a eletrônica e a informática tinham papel fundamental".
} 
a transição do regime autoritário para a democracia; a instauração de um novo marco jurídico-político no país com a convocação da Assembleia Nacional Constituinte (ANC) de 1987-1988, que mudou drasticamente as regras para o funcionamento do Estado e para a legitimação do poder), são precipitados domesticamente no Brasil também graças a constrangimentos sistêmicos do cenário internacional, observados anterior ou paralelamente à ocorrência dessas transformações no cenário político nacional ${ }^{2}$.

Pode-se, desse modo, decompor o processo de modernização da agenda político-econômica nacional (chamemos assim o núcleo essencial definidor dessas três grandes transformações) em duas grandes camadas: a primeira, das instituições e processos políticos domésticos, que resultaram de interações sociais crescentemente infensas à manutenção do status quo político e econômico do regime militar (perda de legitimidade política, com a transformação do perfil da sociedade e da força de trabalho no Brasil; perda de apelo econômico, com a crise do modelo de substituição de importações; disfuncionalidade crescente das instituições do Estado e do aparato legislativo); o segundo patamar corresponde às grandes transformações econômicas e políticas mundiais que, em grande e crucial medida, impeliram às mudanças no cenário doméstico. Sem a pressão política internacional (em seu sentido sociológico sistêmico) as forças sociais internas estariam desprovidas de instrumentos essenciais para desencadear as transformações que conduziriam à modernização política dos anos de 1980; sem a

\footnotetext{
${ }^{2}$ Na perspectiva do holismo metodológico durkheimiano, tais constrangimentos não configuram pressões sistêmicas irresistíveis sobre o comportamento dos atores sociais - no caso, os Estados nacionais -, mas constituem um conjunto de vetores de força que limitam, condicionam e modelam a ação social (Durkheim, 1987). Numa analogia ilustrativa da caracterização do holismo, Ferdinand de Saussure recorre à distinção entre língua (langue) e palavra (parole), conforme a qual a primeira seria um fato social e supraindividual, ao passo que a segunda seria individual, heterogênea e real (Saussure, 1972, pp. 143-50).
} 
organização e a expansão da resistência doméstica ao regime militar, as pressões internacionais não teriam como se infiltrar no cenário político nacional.

Assim, no quadro político da transição democrática no Brasil, a fossilização e o descrédito crescentes da extinta União Soviética (que gradativamente deixava de constituir uma "ameaça"); a plena incorporação das bandeiras da democracia às plataformas dos movimentos de esquerda em nível mundial (o que facilitava o diálogo de setores da esquerda brasileira com o regime no processo de transição) ${ }^{3}$; a cruzada internacional pela promoção dos direitos humanos no Brasil; o gradual fortalecimento do multilateralismo e do direito internacional; o avanço da integração na Europa (que se contrapunha às desconfianças e hostilidades entre regimes militares e antidemocráticos da América Latina) fenômenos aliados, no plano econômico, à difusão de novas tecnologias e serviços nos EUA; à emergência dos países de 220 industrialização recente da Ásia-Pacífico e, por último, à passagem das economias baseadas em matérias-primas para as assim chamadas economias do conhecimento, solaparam as bases de sustentação do pacto industrial-tecnocrático-militar hegemônico, a partir de $1964^{4}$. Passarei a apresentar mais sistematicamente, portanto, o impacto dos constrangimentos sistêmicos internacionais sobre as três fases da modernização brasileira (abertura política, abertura econômico-comercial e advento do Estado democrático de direito, com a promul-

\footnotetext{
${ }^{3}$ Segundo o então líder sindical Luiz Inácio Lula da Silva, a posição oficial do Partido dos Trabalhadores, em 1982, era de apoio ao sindicato polonês Solidariedade, em luta contra a ditadura do General Wojciech Jaruzelski. Tal posição de apoio ao Solidarnösc tornou-se mais firme e evidente à medida que avultavam os sinais de desmantelamento do regime soviético, com o advento da abertura, da transparência e da aceleração econômica na URSS nos tempos de Mikhail Gorbachev. A esse respeito, ver Guattari (1982, pp. 25-6).

${ }^{4}$ Os dois trabalhos que, emblematicamente, assinalariam as grandes transformações políticas e econômicas da ordem internacional no pós-Segunda Guerra Mundial foram publicados na segunda metade dos anos de 1980: Gorbachev (1988) e Drucker (1986).
} 
gação da nova Constituição) nas seções a seguir, começando, cronologicamente, pela abertura política. O objetivo geral e principal deste artigo é o de recuperar, identificar e analisar, ainda que introdutoriamente, as pressões internacionais desencadeantes das principais transformações políticas e econômicas brasileiras observadas nos anos de 1980 .

\section{Distensão, transição e o ocaso do regime militar - o impacto do sistema internacional em transformação}

Desde meados dos anos de 1970, passando pelos anos de 1990, até os dias atuais, o cenário político internacional e doméstico dos países industrializados passou a experimentar um processo de relativa "desideologização": posições mais extremistas ou de princípio, em termos de clivagens tradicionais esquerda-direita, foram perdendo sentido prático nas campanhas eleitorais e nos debates políticos, principal, mas não exclusivamente, nessas democracias avançadas de mercado. Douglas Hibbs (1977) assinalava, em artigo que foi influente entre os anos de 1970 e 1980, que a "grande barganha" (trade-off) entre esquerda e direita na Europa Ocidental, EUA e Japão, a partir da Segunda Guerra Mundial, resumir-se-ia à "curva de Phillips" (correlação histórica inversa entre as taxas de desemprego e inflação na economia): enquanto liberais e social-democratas esforçar-se-iam por reduzir as taxas de desemprego, às expensas da inflação, conservadores e republicanos atacariam a inflação, com prejuízos para os níveis de emprego. Joseph Lapalombara (1966) sustenta, conhecido artigo, de modo semelhante que os partidos europeus já vinham abandonando as clivagens ideológicas e de classe para transformarem-se em instituições menos ideologizadas, voltadas para a administração justa ("imparcial"), racional e eficiente dos recursos e demandas da sociedade (partidos catch all).

Uma das consequências políticas mais marcantes para o Brasil e para a América Latina das transformações do euro- 
comunismo, do reformismo e do programa dos partidos de esquerda do Ocidente nos anos de 1960 e de 1970 foi a ampla incorporação das bandeiras democráticas para o campo "progressista", com o consequente abandono das estratégias de chegada ao poder pela via revolucionária violenta ${ }^{5}$. O fato de a repressão no Brasil haver também incorporado e tolerado certa expressão oposicionista - o que levou, por exemplo, à memorável vitória do MDB nas eleições legislativas de 1974 (com votações invariavelmente expressivas para os candidatos "autênticos", tais como Alencar Furtado, Fernando Lyra, Francisco Amaral, Lysâneas Maciel e Paes de Andrade) ${ }^{6}$ - desacreditou, em alguma medida, a posição dos muitos que, particularmente a partir de 1968, vislumbravam no levante armado a única forma de derrubar o regime, restaurar o Estado de direito e construir a democracia. Ampla e insuspeita literatura brasileira dos anos de 1960, a começar por Prado Júnior (1966), passou 222 a denunciar de maneira sistemática a transplantação artificial de categorias marxistas-leninistas para uma realidade social brasileira que se diferenciava substancialmente das relações sociais e de produção mais específicas de economias asiáticas pré-revolucionárias e europeias do século XIX7 .

O descrédito da luta armada como instrumento de transformação social; a revisão das estratégias da esquerda internacional (agora mais voltadas para o que seria um

\footnotetext{
${ }^{5}$ Uma parcial e improvável exceção, nos dias atuais, seria a ação das Forças Armadas Revolucionárias da Colômbia (Farc).

${ }^{6}$ Para depoimentos dos "autênticos", ver o documento de Nader (1998).

7 " [...] tanto quanto a deformada visão da economia e das relações de produção e classe no campo brasileiro [...] a ideia de uma 'burguesia nacional' progressista e contrária ao imperialismo por sua posição específica de classe, causou à linha política da esquerda os mais graves danos. Foi ela certamente um dos fatores que contribuíram para levar as esquerdas por caminhos errados e cheios de ilusões que deram no desastre de abril de 1964" (Prado Júnior, 1966, p. 112). Caio Prado critica a ortodoxia de setores então hegemônicos da esquerda brasileira, que os teriam impedido de negociar uma política de alianças com a ala mais moderada dos movimentos conservadores no Brasil pré-1964.
} 
"evolucionismo bernsteiniano") ${ }^{8}$; as vitórias e ocupação de espaços pela esquerda progressista brasileira nos meandros da sociedade civil e nas posições de Estado; o "código genético" básico do regime de que não deveria se manter indefinidamente no poder (expresso em sua própria predisposição de, contrariamente às ditaduras convencionais, limitar mandatos presidenciais); a hegemonia da ala "castelista" no aparato tecnocrático-militar, entre outras realidades políticas da época, fizeram com que o regime militar mantivesse abertos certos canais institucionais de negociação com as oposições, no âmbito do Estado, com o consequente arrefecimento da influência de setores mais radicais de direita.

No plano dos direitos humanos, as denúncias de violações no Brasil, formuladas pelas imprensas europeia e norte-americana, as críticas do governo Carter, as ameaças de sanções - que nunca vieram efetivamente a se concretizar e os constrangimentos a que o próprio presidente Geisel foi submetido em viagens ao exterior, certamente ajudaram a animar e a impulsionar movimentos de abertura e distensão e a fomentar o diálogo com setores da oposição no Brasil ${ }^{9}$.

\footnotetext{
8 A burocratização do comunismo soviético e do "socialismo real" como um todo ensejou um amplo movimento de revisão e crítica, a partir da própria esquerda, que passou a preconizar uma "terceira via" (que não se confunde com os postulados de natureza mais econômico-liberal de Anthony Giddens) entre o socialismo real e o livre-mercado de cunho neoclássico. A esse respeito, ver Bahro (1980) e Wilczynski (1972, pp.211-8).

${ }^{9}$ Em visita oficial ao Reino Unido, em maio de 1976, o presidente Geisel foi forçado a enfrentar diversos protestos em seus três dias de permanência em Londres. Os dois principais partiram da própria base do Partido Trabalhista na Câmara dos Comuns: 60 deputados do grupo parlamentar de direitos humanos enviaram dura carta ao presidente denunciando que "prisões políticas, torturas e desaparecimentos inexplicados de cidadãos brasileiros estão novamente acontecendo, em escala alarmante". Outras duas manifestações inesperadas de protesto partiram do arcebispo católico de Westminster, George Basil Hume, e do próprio primeiro-ministro James Callagham. Este último, em almoço com o presidente Geisel, provocou dizendo que "Brasil e Reino Unido muito teriam a colaborar no campo da promoção dos direitos humanos" (Veja, 1976, pp. 19-20). A própria livre-divulgação de tais críticas e constrangimentos, pela imprensa brasileira, é em si um fato que viria a reforçar o processo de descrédito do regime.
} 
Diante das pressões do governo Carter para que o regime militar passasse a condenar o uso da tortura e a observar o respeito aos direitos humanos no Brasil, o grupo linha-dura comandado pelo então ministro do Exército de Geisel, o general Sylvio Frota ${ }^{10}$, teve ainda mais reduzidas suas chances de influir significativamente no processo sucessório de Geisel sem recorrer a um novo "golpe dentro do golpe", tal como ocorrera em dezembro de 1968, com a decretação do Ato Institucional n. 5.

Os constrangimentos vividos por Geisel na visita ao Reino Unido em 1976 repetir-se-iam no ano seguinte, desta vez em Brasília e após a decretação do "Pacote de Abril". O presidente Jimmy Carter havia enviado sua própria mulher, Rosalynn (a "Magnólia de Aço"), para um périplo de duas semanas por sete países latino-americanos então assolados por regimes de exceção. Geisel, que a despeito de sua grande relutância fora forçado a 224 receber uma representante norte-americana sem cargo definido na estrutura do governo, foi diretamente confrontado sobre a situação dos direitos humanos no Brasil, em jantar no Palácio da Alvorada, que se deu em 10 de junho de 1977:

Quando se reuniram, Geisel ouviu-a recitar "o compromisso decidido de seu marido com a causa dos direitos humanos": "a política exterior norte-americana deve representar o que há de melhor nos Estados Unidos e [...], por isso mesmo, não seria possível aceitar, fora de suas fronteiras, o que tampouco aprovava internamente (sic)”. Rosalynn admitiu que a posição americana "poderia gerar certos mal-entendidos a curto prazo",

\footnotetext{
${ }^{10}$ Na Câmara dos Deputados, o chamado "grupo frotista" era coordenado pelo deputado Sinval Boaventura, presidente da Comissão de Segurança Nacional, e integrado por 113 deputados do partido governista, a Arena (Jornal do Brasil, 1977).
} 
mas mostrou-se convicta de que "acabariam por prevalecer os princípios morais"11.

Outro episódio indicativo de como o regime militar era particularmente sensível às críticas de governos e setores da opinião pública dos países industrializados, notadamente dos EUA, foi a força-tarefa, montada no segundo semestre de 1973, pela área econômica do governo Médici para pressionar Paul Samuelson, professor do Massachussets Institute of Technology (MIT), a retirar de sua celebrada obra Economics a menção de que o Brasil estaria sendo "governado por fascistas”. Ao menos Eugênio Gudin, Mário Henrique Simonsen, Golbery do Couto e Silva e Roberto Campos foram convocados para convencer o economista norte-americano a retirar tal menção desairosa ao Brasil. Samuelson acabou por aceitar as pressões para que se alterassem os trechos correspondentes na tradução brasileira da obra ${ }^{12}$.

No plano econômico, a estratégia do "ajuste mitigado" levada a cabo durante o governo Geisel na gestão do ministro da Fazenda Mário Henrique Simonsen, acoplou-se então ao conceito de "pragmatismo responsável" da política externa, conforme o qual o Brasil necessitaria abrir novos espaços e mercados para suas exportações, tanto para sustentar o projeto desenvolvimentista, quanto para contornar os efeitos da crise do petróleo (e, mais tarde, já no gover-

\footnotetext{
${ }^{11}$ Registro da conversa da Senhora Rosalynn Carter com o presidente Ernesto Geisel por ocasião do jantar oferecido no Palácio da Alvorada, segundo anotações da intérprete, Senhora Ulla Schneider, de 10 de junho de 1977 (apud Gaspari, 2004, p. 393). Ainda durante a visita de Rosalynn ao Brasil, o deputado "autêntico" emedebista Alencar Furtado chegou a sugerir à visitante a adoção de sanções econômicas ao Brasil como forma de pressionar o regime a respeitar os direitos humanos. A bancada do MDB optaria mais tarde, entretanto, por não levar adiante a iniciativa. Já em novembro de 1965, o senador norte-americano Bob Kennedy, em visita ao Brasil, discursaria no sindicato dos metalúrgicos de São Paulo, criticando a restrição às liberdades no país e manteria, por ocasião da viagem, conversas ásperas sobre o tema com o chanceler Juracy Magalhães e com o ministro da Fazenda, Roberto Campos.

${ }^{12} \mathrm{O}$ episódio está narrado em detalhes em Gaspari (2004, pp. 264-8).
} 
no Figueiredo, os efeitos da crise da dívida). Esse binômio impeliu o Brasil a tomar decisões no plano externo que apareceriam, à primeira vista, incongruentes com o discurso de Geisel - expresso tanto na mencionada visita ao Reino Unido quanto nas reuniões com Rosalynn Carter - de que o Brasil possuía, em relação às motivações estratégicas dos EUA, "características e necessidades próprias" para o enfrentamento do comunismo. Entre as decisões mais polêmicas de política externa do governo Geisel, situa-se, como se sabe, o reconhecimento diplomático da China de Mao Tsé-Tung (cujo regime teria sido responsável pelo extermínio de mais de 70 milhões de pessoas em seu próprio país) (Chang e Halliday, 2007, p. 3); o célere e pioneiro reconhecimento da independência de Angola e do regime do Movimento Popular para a Libertação de Angola (MPLA); a decisão, tomada pessoalmente por Geisel, de considerar o sionismo como "uma forma de racismo e de discriminação 226 racial”, em apoio à Resolução n. 3379 da Assembleia-Geral das Nações Unidas, de 1975.

Embora, para caracterizar as causas principais que levaram o Brasil a esses três movimentos surpreendentes de política externa, seja difícil e desnecessário realizar uma separação conceitual mais rigorosa entre pressões estruturais externas e as decisões estratégicas domésticas de parte de um regime autoritário "de direita"13, trata-se de um fato que a crise do petróleo determinou pragmaticamente essa reorientação externa por parte do regime na direção de alianças e mercados que pudessem mitigar a vulnerabilidade à crise energética e dar uma sobrevida tanto ao modelo desenvolvimentista e de fortes investimentos em infraestrutura quanto, consequentemente, ao próprio regime. Nesse aspecto, ao menos seis movimentos políticos marcantes combinaram-

\footnotetext{
${ }^{13}$ Isto é, alinhado com os EUA na Guerra Fria, cerceador de liberdades democráticas e promotor de um modelo de capitalismo associado e dependente dos principais centros financeiros e produtivos mundiais.
} 
-se para refrear a influência da "linha-dura" no regime e preparar o caminho para a abertura política: a) a pressão externa contra o regime militar, especialmente na questão do desrespeito aos direitos humanos ${ }^{14}$; b) o ambiente político internacional menos propício, quando comparado aos anos de 1950 e 1960, para o confronto bipolar e ideológico direto (crise de Berlim, crise dos mísseis de Cuba, guerra da Coreia) ${ }^{15}$; c) o arrefecimento do radicalismo da esquerda brasileira após 1974, com a vitória do MDB e o recrudescimento da influência dos "autênticos"; d) a crise energética dos anos 1970 e o "pragmatismo responsável” da política externa; e) consequentemente, a aproximação do regime militar brasileiro de teses de política externa mais condizentes com uma plataforma "democrática" e "de esquerda"16 e f) o interesse de o regime militar brasileiro diferenciar-se de regimes mais sanguinários e repressores da América Latina dos anos de 1970, notadamente os da Argentina e do Chile.

É evidente que uma ampla mobilização da sociedade brasileira, a partir de entidades da sociedade civil como a Ordem dos Advogados do Brasil (OAB), a igreja católica, o novo sindicalismo surgido no anel industrial de São Paulo, jornais de grande circulação do eixo Rio de Janeiro-São

\footnotetext{
${ }^{14}$ O então arcebispo de São Paulo, Dom Paulo Evaristo Arns, chegou a enviar carta ao presidente Jimmy Carter com o nome de 23 desaparecidos políticos, com pedido de que os EUA exigissem do Brasil informações oficiais sobre o seu paradeiro (Folha, 1991a, p. 80).

${ }^{15}$ Em novembro de 1983, ocorreria ainda a operação naval Able Archer da Otan, que suscitaria enérgicas reações de Moscou, o qual chegou inclusive a considerar a possibilidade de retaliação nuclear. Este teria sido, entretanto, o último episódio mais grave de confronto direto entre as superpotências na Guerra Fria e o único desde a Crise dos Mísseis de outubro de 1962. Diferencia-se dos confrontos anteriores por ter tido escassa cobertura e análise pela imprensa mundial da época, tendo sido tratado com grande grau de sigilo pelas partes.

${ }^{16} \mathrm{O}$ Brasil reconheceu o governo da República Popular da China somente em agosto de 1974, após o México e a Argentina, que o haviam reconhecido em fevereiro de 1972, dias antes do embarque do presidente Richard Nixon para sua histórica visita à China (entre os dias 21 e 28 de fevereiro de 1972). Excelente análise das motivações da aproximação dos países latino-americanos, e do Uruguai em particular, com a China, está contida em Saus et al. (2007).
} 
Paulo, o movimento estudantil, setores do empresariado e especialmente movimentos de expressão cultural como o teatro do oprimido e a Música Popular Brasileira, foi determinante para a resistência, a partir de uma perspectiva propriamente doméstica e interna. Uma característica fundamental desse movimento de resistência foi o fato de atuar no âmbito das regras da transição traçadas pelo próprio regime, ainda que talhadas sob o manto dos inumeráveis casuísmos que buscavam procrastinar o início efetivo do processo de (re)democratização do país. Num contraste pronunciado, a direita agrupada na linha-dura (favorável ao controle pleno e indeterminado do Estado e do processo político pela burocracia e pelo estamento militar) colecionava tragédias e fracassos, com a morte de presos políticos em delegacias de polícia e centros de tortura, atentados frustrados e ações patéticas como a perseguição a setores da imprensa, o que servia para afastar definitivamente a 228 sociedade brasileira das tentativas de sobrevida do regime. À medida que se tornava difícil fazer chegar à sociedade de um modo geral a diferença entre "castelistas" e "costistas" nas disputas de bastidores do regime militar, tais manifestações de repúdio manifestavam-se em derrotas eleitorais acachapantes da Arena (acomodadas precariamente pelos mesmos casuísmos); na decretação da Lei de Anistia; na reforma partidária de novembro de 1979 e no início das manifestações de massa e da sociedade para que o sucessor do general Figueiredo fosse um civil eleito diretamente.

O fato, porém, de todos os regimes militares e autoritários da América Latina terem sucumbido a partir de movimentos políticos, civis e sociais sincrônicos durante os anos de 1980, indica a existência de uma coordenação mais ampla, em nível sistêmico, que correlacionava movimentos domésticos e internacionais em prol da democratização, e que estes teriam sido um esteio para que aqueles viessem a triunfar na luta pela abertura e pela democratização no Brasil 
e no continente de modo geral. Tal conjunção de fatores sugeriria a um observador da primeira metade dos anos de 1980 que o regime estaria ferido de morte e que somente uma brutal (e totalmente desnecessária e contraproducente) repressão poderia dar-lhe alguma sobrevida. Os resultados eleitorais de novembro de 1982 e, mais importante ainda, o posterior início da Campanha Diretas Já, iriam corroborar amplamente esse vaticínio.

Tiveram ampla repercussão no Brasil e coincidiram com o advento da globalização política - pela qual determinados princípios e valores deixaram de se restringir às esferas domésticas para se transformarem em referências mundiais, e vice-versa - a visita de Nixon à China em 1972; o grande movimento de abertura econômica na direção das reformas de mercado, após a morte de Mao (as "quatro modernizações" e a "política de portas abertas" de Deng Xiaoping); o início da détente entre EUA e a URSS (e apesar do recrudescimento da crise com a invasão soviética do Afeganistão, em 1979); a ascensão do arquiliberalismo thatcheriano no Reino Unido e até mesmo os desafios lançados pelo Papa João Paulo II ao comunismo soviético. Ideais como paz, democracia e respeito aos direitos humanos passaram a prevalecer nas relações internacionais, impondo custos severos a países que, como o Brasil de então, não estivessem dispostos a sustentá-los.

Outro fator, entretanto, de ordem manifestamente econômica global, ajudaria a precipitar, juntamente com a crise do regime, uma crise de Estado no Brasil, com o colapso do modelo desenvolvimentista e o esgotamento do modelo de substituição de importações. A década de 1980, tida como "perdida", testemunharia, no entanto, o vigoroso programa de reformas políticas de fundo no Brasil, que foram também impulsionadas pela incapacidade de o regime responder convincentemente às crises mundiais e de propor um modelo alternativo de inserção econômica internacional. 
Passarei a seguir à análise das causas internacionais - amplamente predominantes em relação às propriamente domésticas - da crise de Estado no Brasil.

\section{Economia "retardatária" e os novos desafios globais}

À medida que possamos admitir que processos como a convocação da ANC pelo então presidente José Sarney, por intermédio da Emenda Constitucional n. 26, de 1985, a democratização do país e a abertura política conjugam-se com a crise de Estado da primeira metade dos anos de 1980 (crise essa, por sua vez, resultante do colapso do modelo desenvolvimentista a partir dos anos de 1970). O passo seguinte seria descrever e analisar os fatos correspondentes às pressões mais manifestamente internacionais sobre a crise e, consequentemente, no plano da economia política, sobre as transformações políticas internas cruciais desses mesmos anos de 1980.

230 As origens internacionais da crise econômica dos períodos Figueiredo e Sarney podem ser agrupadas em três níveis básicos de análise, que naturalmente não são estanques, mas que fluem de um cenário macroestrutural mais amplo para descer ao nível da conjuntura, até a chegada, por exemplo, da missão Struckmeyer do FMI ao Brasil, ao final de novembro de 1982 - quando já haviam sido apurados os resultados das eleições gerais (menos para presidente) de 1982, as primeiras desde o golpe de 1964. O primeiro nível refere-se às mudanças estruturais da economia internacional, que penalizaram particularmente países emergentes da dimensão do Brasil, de economia intensiva em matérias-primas; um segundo nível, intermediário entre a estrutura e a conjuntura, refere-se ao impacto das crises da dívida e das duas do petróleo sobre os fundamentos da economia brasileira, e o terceiro nível seria o impacto de ambos os anteriores sobre o emprego, o consumo das famílias, a taxa de inflação, a poupança externa, a produtividade geral dos 
fatores e o balanço de pagamentos do Brasil (indicadores macroeconômicos). A conjugação desses níveis de análise demonstra como se tornou insustentável para o regime militar a manutenção das metas dos II e III Planos Nacionais de Desenvolvimento (esteios do "Estado desenvolvimentista") e seu projeto de legitimação via resultados econômicos favoráveis, em parte verificados no governo Geisel e, sobretudo, durante o governo Médici alguns anos antes.

\section{As mudanças na economia mundial}

Como se sabe, o modelo de substituição de importações (SI) trouxe importantes consequências benéficas para a industrialização, a instalação da infraestrutura, da indústria de base e da competitividade das exportações brasileiras, modelo cuja mola-mestra baseava-se em quatro componentes essenciais: fácil acesso ao mercado internacional de crédito e capacidade de endividamento externo para o financiamento de políticas de desenvolvimento, por conta dos juros baixos praticados por Bancos Centrais europeus e pelo Federal Reserve dos EUA, diante da disponibilidade de petrodólares e eurodólares (Silva, 2004, p. 457); tarifas domésticas de importação elevadas (protecionismo tarifário); forte intervenção no mercado cambial, também com vistas à correção dos fatores de competitividade das exportações e mercado internacional de produtos primários e semimanufaturados aquecido. Como se viu anteriormente, essa combinação de fatores permitiu ao Brasil ocupar, durante longo tempo, níveis superiores a $2 \%$ no conjunto da corrente internacional de comércio e níveis médios de crescimento de 7\%, ao longo da década de 1970.

Mudanças estruturais da economia mundial demandam mais tempo para serem assimiladas, percebidas e sistematizadas pela análise científico-acadêmica que as mudanças de cunho propriamente político. No caso destas, o fim da Guerra Fria e do sistema bipolar tiveram como epifenô- 
meno claramente discernível a Queda do Muro de Berlim, em outubro de 1989. No caso das mudanças econômicas, estas se processam de modo incremental, e normalmente é mais difícil aos tomadores de decisão antecipar tendências e desvincular-se das pressões do cotidiano, o que os leva a gerar respostas e a executar políticas cujos resultados não são plenamente previsíveis ou que, não raro, acarretam consequências não pretendidas. Tais mudanças econômicas incrementais são normalmente produzidas por mecanismos evolutivos do capitalismo, que plasmam a competitividade dos países e atores econômicos e criam barreiras para os movimentos e tendências de transformação do perfil produtivo e da divisão internacional do trabalho de parte dos países retardatários, ou late comers.

Das grandes transformações da economia internacional, ao menos desde o pós-Segunda Guerra, porém, mais caracteristicamente, a partir dos anos de 1970, pode-se sintetizar, 232 seguindo Drucker (1986), como principais: a desvinculação da produção de matérias-primas da produção industrial e do preço do produto industrial; a separação do emprego industrial da produção industrial e a desconexão entre comércio e finanças internacionais. Tais transformações podem ser sintetizadas na fórmula simplificada "da passagem da macroeconomia do Estado-nação para a macroeconomia internacional" (Drucker, 1986, p. 769). Ainda que este trabalho não comporte uma avaliação minuciosa desses três fenômenos, indicarei, em níveis mais genéricos, como impactaram a economia brasileira e as pretensões desenvolvimentistas dos governos Geisel e Figueiredo.

A desvinculação da produção de matérias-primas da produção industrial teve efeitos bastante perversos, em séries históricas longas, sobre a competitividade das exportações brasileiras a partir de meados dos anos de 1970. Se nos anos de 1950, de 1960 e parte dos de 1970, o preço internacional de produtos como o café, a soja, o milho e 
a carne bovina podiam financiar o processo de desenvolvimento, assegurar a formação de reservas, promover a industrialização e a montagem da infraestrutura nacional, esse processo foi gradativamente refreado pelo impacto da evolução tecnológica sobre a produção mundial. Um exemplo, citado pelo próprio Drucker (1986, p. 773), é a demanda por cobre, que caiu drasticamente com o aproveitamento industrial da fibra ótica (25 quilos de terminais de fibra ótica têm o mesmo desempenho que uma tonelada de cobre, na indústria das telecomunicações e da informação).

A segunda grande transformação derivou diretamente da primeira e gerou profundos impactos sobre a estrutura produtiva brasileira. Numa economia agrário-exportadora, ou exportadora predominantemente de bens e serviços de baixo valor agregado, a mão de obra assalariada também terá forçosamente baixa qualificação, o que, por sua vez, acarreta a formação de uma massa salarial achatada e de uma força de trabalho pouco competitiva. As dificuldades históricas da economia brasileira para gerar setores terciários e quaternários de ponta (devido, em linhas gerais, à baixa competitividade desta), impediram o país de alcançar a terceira revolução industrial e de acompanhar os movimentos das economias recém-industrializadas da região da Ásia-Pacífico e da Europa, nos anos de 1970, conforme também salienta Sallum Júnior (1996, pp. 168-9) ${ }^{17}$. Políticas de desenvolvimento produtivo baseadas na consolidação de uma indústria pesada e pouco intensiva em conhecimento retardaram ou impediram o catch up do Brasil com essas economias recém-industrializadas, para não mencionar com os países

\footnotetext{
${ }^{17}$ Sobre o desempenho geral das economias dos países emergentes e em desenvolvimento nos anos de 1960 a 1980, ver Kennedy (1993, pp. 193-211), especialmente o capítulo 10; sobre as estratégias bem-sucedidas de desenvolvimento e industrialização das economias recém-industrializadas da Ásia-Pacífico, ver Chang (2003, pp. 92-4).
} 
industrializados propriamente $\operatorname{ditos}^{18}$. Embora a economia brasileira já dispusesse então de um parque tecnológico razoavelmente diversificado, estava muito distanciado do perfil das economias industrializadas (Carvalho e Lima, 2007, p. 17). É consenso na análise econômica dos anos de 1980 no Brasil e na América Latina que, caso os termos de intercâmbio do agronegócio e das commodities brasileiras e dos demais países da região não tivessem experimentado a deterioração do período 1975-1985, certamente não teria sobrevindo a crise econômica que resultou na "década perdida" dos anos de 1980, ao menos não na intensidade e duração verificadas; o Brasil ter-se-ia industrializado em grande medida e a economia japonesa, por exemplo, ter-se-ia estagnado (a estagnação japonesa chegaria de fato nos anos de 1990, mas por motivos bastante diferentes). Na realidade, porém, o Japão passou a dispor de matérias-primas abundantes e baratas no mercado internacional e o Brasil 234 não contou, por sua vez, com receitas de exportação que permitissem estancar seu endividamento.

A crise internacional dos anos de 1980, que golpeou severamente a economia brasileira, guarda relação causal direta com o fortalecimento das oposições e da sociedade civil, além do advento de movimentos políticos que tiveram papel crucial no desmantelamento do regime e na precipitação da crise de Estado no Brasil. É sintomático, por exemplo, que o movimento sindical do anel industrial de São Paulo tenha surgido ao final dos anos de 1970, graças à relativa modernização da economia brasileira que per-

\footnotetext{
${ }^{18}$ Exemplos de vozes que alertavam, no Brasil, durante o período de SI, sobre os riscos de um modelo de industrialização baseado em vantagens comparativas estáticas (fora da comunidade acadêmica de economia e além do pensamento da Comissão Econômica para a América Latina e o Caribe das Nações Unidas/Cepal) foram as do Almirante Álvaro Alberto da Motta e Silva, primeiro presidente do Conselho Nacional de Desenvolvimento Científico e Tecnológico (CNPq), e do professor Luiz Alberto Coimbra, fundador da Coordenação de Pós-Graduação e Pesquisa em Engenharia da Universidade Federal do Rio de Janeiro (Coppe/UFRJ).
} 
mitiu a transformação das relações de trabalho urbanas no país. Pouca dúvida haveria quanto à correlação entre endividamento externo, aumento de $200 \%$ do preço do barril de petróleo/FOB, aumento de $200 \%$ na taxa internacional de juros, desemprego, inflação, recessão, arrocho salarial, maxidesvalorização e o recrudescimento do ativismo político-partidário e na sociedade em geral contra o regime militar.

Entretanto, por conta das desconexões assinaladas por Drucker (1986) entre matérias-primas e produção industrial, por um lado, e entre produção industrial e emprego industrial, por outro, as mais de 3 mil empresas do setor metal-mecânico que se localizavam nesse anel e que participavam diretamente da cadeia produtiva do setor automobilístico, foram reduzidas para menos de 300 nos tempos atuais (com a produção de automóveis sendo cada vez mais internacionalizada e menos intensiva em matérias-primas e mais em componentes eletrônicos, softwares, patentes e novos materiais, por exemplo). Esse dado ilustra claramente as raízes sociológicas e políticas do surgimento de um partido como o PT, criado essencialmente numa "janela" histórica delimitada de transição: entre o apogeu da industrialização resultante da SI e o começo do declínio de um modelo de industrialização incompleta ou interrompida (Furtado, 1992).

A terceira desconexão estrutural da economia mundial deu-se com a desvinculação entre produção e mercados financeiros. Se o comércio internacional até basicamente os anos de 1960 guardava alguma relação com o nível de investimentos e o estoque de capitais e $\operatorname{reservas}^{19}$, com o primeiro choque do petróleo vicejou um agressivo mercado de derivativos e de papéis secundários, que começaram a ser despejados numa economia promissora como a brasileira, que, por meio de juros altos, continha a inflação e atraía

\footnotetext{
${ }^{19}$ Segundo os neoclássicos, o nível de comércio exterior de um país é uma função direta de sua disponibilidade de capitais; para os keynesianos, a disponibilidade de capitais é uma função dos níveis de comércio praticados por um país.
} 
investimentos externos. Foi o início de um processo de privatização da dívida externa brasileira. Na primeira missão do Fundo Monetário Internacional (FMI) ao Brasil do período militar, em fins de 1982, o país devia a 1.114 bancos privados dos países industrializados, com um núcleo principal de 40 com os quais o governo negociava as condições de pagamento, rolagem e amortização (Skidmore, 1988, p. 452$)^{20}$. Com a economia brasileira em crescente desconfiança, alimentada pela moratória mexicana de agosto de 1982, a taxa de investimentos externos declinou até o ponto em que o estoque de reservas internacionais do país passou a ser tratado como "segredo de Estado" (Veja, 1982, p. 146). Com a deterioração dos preços das principais exportações brasileiras, a posterior fuga maciça de capitais e a perda da capacidade de financiamento do desenvolvimento, a economia brasileira mergulhou em profunda recessão e desemprego (inflação de $95 \%$ e recessão, em termos de PIB 236 per capita, de 4,3\%, em 1981). Assim, com a migração dos investimentos especulativos para economias mais sólidas da Europa, EUA e Ásia-Pacífico, a defasagem tecnológica e industrial entre as economias latino-americanas e as industrializadas e emergentes tornou-se ainda mais acentuada ${ }^{21}$. Nos primeiros anos da década de 1980, sentia-se que a crise econômica brasileira era ainda mais severa do que a que havia acometido o país às vésperas do Golpe de 1964.

O ocaso do regime militar coincide e é precipitado, assim, por mudanças drásticas e punitivas do padrão de

\footnotetext{
${ }^{20}$ Para uma excelente síntese, inclusive com quadros sinóticos completos, sobre o relacionamento do Brasil com o FMI e com o sistema de Bretton Woods, ver Almeida (2002).

${ }^{21}$ Empréstimos do governo norte-americano durante a crise, integralizados antes das eleições de novembro de 1982, tiveram como contrapartida diversas concessões brasileiras, como a adesão do país ao código de subsídios do então Acordo Geral de Tarifas e Comércio (Gatt), que limitava os incentivos às manufaturas brasileiras, contribuindo para os baixos níveis de crescimento dos anos de 1980 e para o advento da "década perdida" (Ricupero apud O Globo, 2012).
} 
acumulação da economia brasileira baseado em fatores espúrios de competitividade ${ }^{22}$, tais como mão de obra barata, baixos coeficientes de empregabilidade, legislação trabalhista leniente com os empregadores, patrimonialismo, ausência de marcos regulatórios e de sistemas de proteção ao consumidor, além da ocorrência de juros internacionais relativamente mais baixos e competitividade relativamente mais elevada dos produtos primários.

A condição brasileira de país retardatário (late comer) assolado pela inflação, por sucessivos períodos de recessão, de endividamento, de paralisia na capacidade de investimento e de déficit nas contas nacionais - compôs o quadro da crise do Estado desenvolvimentista. Daí resultaram o esgotamento do modelo de substituição de importações e dos instrumentos de proteção social advindos do Estado Novo. Se para a materialização desse quadro as transformações da economia mundial observadas na época desempenharam papel-chave, o impacto da conjuntura econômica internacional (e não somente das mudanças estruturais) também se somou para golpear as evanescentes pretensões de legitimidade e de continuidade do regime militar.

\section{A doutrina da contenção e seu impacto na economia brasileira dos anos de 1980}

$\mathrm{Na}$ avaliação dos fenômenos históricos, como os que causaram as profundas transformações na sociedade brasileira nos anos de 1980, seria falso supor que tais mudanças do

\footnotetext{
${ }^{22}$ Segundo Sutz (2000, p. 287), “[Nesse cenário,] a desigualdade estimula a adoção de opções fáceis do tipo competitividade espúria, baseada em salários baixos e uso insustentável de recursos naturais, parca atenção a direitos trabalhistas, baixa prioridade à formação e educação de trabalhadores e estratégias curto-prazistas de maximização do lucro. Quando a grande maioria das empresas pode sobreviver e mesmo crescer dessa forma, isto é, evitando os desafios da competitividade estrutural baseada no conhecimento e na aprendizagem, será difícil que as universidades sejam reconhecidas como parceiras potenciais no processo de desenvolvimento e de crescimento econômico".
} 
modelo brasileiro de desenvolvimento decorreram apenas de causas econômico-estruturais exógenas. Para a crise de Estado brasileira e para a inviabilização do modelo econômico dos anos de 1980 concorreram, sobretudo, fatores políticos, principalmente de origem internacional. Nesse particular, a dinâmica da Guerra Fria, da bipolaridade ideológica e da doutrina da contenção EUA-URSS desempenharam papel determinante na crise brasileira, no solapamento das bases de sustentação do regime militar e no consequente revigoramento das oposições e da esquerda democrática no nível interno.

Após o êxito relativo da estratégia de ajuste mitigado durante o governo Geisel, que permitiu ao Brasil crescer a taxas médias anuais de $7 \%$, o governo Figueiredo viu-se forçado a tentar conciliar a manutenção desse desempenho com a necessidade de controlar a inflação e corrigir os desajustes no balanço de pagamentos. $\mathrm{O}$ desaquecimento 238 da economia global, puxado pela crise do petróleo, reduzia a demanda global pelos produtos da pauta brasileira de exportações e aumentava o déficit em transações correntes, sobretudo, por conta da necessidade de prosseguir importando bens de capital.

O ministro Mário Henrique Simonsen chegara a cogitar a revisão da estratégia de crescimento e de ajuste mitigado consubstanciada no II PND. O resultado certo, porém, seria a estagnação, acompanhada de desemprego, recuo generalizado da atividade produtiva e perda de competitividade nas exportações, alimentando assim o ciclo do estancamento econômico. A opção de seguir com a política de crescimento estava estrategicamente associada ao gradualismo da abertura política, da modernização e do projeto de democratização do país.

A crise no balanço de pagamentos e o endividamento externo, consequências diretas da manutenção do modelo de crescimento (que não pressupunha necessariamente 
o desenvolvimento), foram agravados durante o governo Figueiredo. Os vultosos empréstimos externos contratados a juros flutuantes pelo governo Geisel para financiar a instalação da infraestrutura energética, de transportes e de comunicações ${ }^{23}$, não tiveram como gerar retornos financeiros já no governo Figueiredo (uma vez que pressupunham prazos de maturação longos), o que agravou ainda mais endividamento num contexto de falta de opções para a elevação da competitividade da economia brasileira, a curto ou a médio prazo.

O comprometimento definitivo das pretensões de crescimento econômico e de estabilização do balanço de pagamentos durante o governo Figueiredo veio com a explosão do déficit norte-americano a partir do primeiro mandato de Ronald Reagan. A invasão do Afeganistão pela URSS no Natal de 1979 e o desafio imposto pela Revolução Islâmica no Irã, também em 1979 (inclusive com a invasão da embaixada norte-americana por militantes da Universidade de Teerã), motivou Reagan a ampliar consideravelmente os gastos na área de defesa, em relação ao período de Jimmy Carter. Essa expansão dos gastos norte-americanos - embora em termos de expectativas, e não de efetivo comprometimento orçamentário para o programa - chegou ao clímax com a proposição da Iniciativa de Defesa Estratégica (SDI), projeto que previa a alocação de 37,1 bilhões de dólares para o quinquênio 1987-1991, valor que corresponderia à totalidade dos recursos alocados à pesquisa e desenvolvimento do Exército norte-americano.

Para cobrir esse acréscimo extraordinário ao orçamento militar do país, o governo Reagan decidiu emitir

\footnotetext{
${ }^{23}$ Os conhecidos exemplos dessa instalação, que requereram vultosos empréstimos internacionais, foram, entre outros, a construção da usina de Itaipu, a ponte Rio-Niterói, os sistemas de metrô do Rio de Janeiro e de São Paulo, o financiamento da usina nuclear de Angra e os projetos de siderurgia no âmbito do II PND, especialmente o de criação da Açominas.
} 
títulos do Tesouro norte-americano que, entretanto, não viriam a ser cobertos pelo Federal Reserve pelo temor das inevitáveis pressões inflacionárias. Diante dessa recusa, o governo foi forçado a elevar exponencialmente as taxas de juros para a captação de recursos no mercado, o que veio a acarretar a elevação das taxas em todo o sistema. Como resultado um tanto contraproducente dessa estratégia, cresceu o estoque da dívida pública norte-americana - ainda que as emissões dos títulos do tesouro tenham logrado atrair eurodólares e petrodólares para os EUA nesse contexto crucial de financiamento do seu complexo industrial-militar ${ }^{24}$.

O impacto dessa brutal elevação de juros foi fatal para os países latino-americanos e do Leste Europeu, estes então na esfera de influência soviética. As consequências mais visíveis foram o colapso das contas públicas em países como Polônia e Argentina e a moratória mexicana 240 de agosto de 1982. No Brasil, além das consequências negativas sobre o balanço de pagamentos, a medida teve como resultado: o início da recessão; o esgotamento da capacidade de endividamento externo; o abandono das pretensões de crescimento e o recrudescimento da inflação. Diante da inevitabilidade da desvalorização do cruzeiro, para tornar as exportações mais competitivas, o país viu-se paradoxalmente forçado, no âmbito da Rodada Uruguai do Acordo Geral de Tarifas e Comércio (Gatt) a suprimir diversos subsídios e medidas de apoio às exportações. Esse quadro levou o país a recorrer ao FMI, como já se viu, e a submeter-se ao pacote com condicionalidades que impôs um alto custo político ao governo. Os ingredientes conjunturais para a deflagração da crise de Estado e do modelo de substituição

\footnotetext{
${ }^{24} \mathrm{~A}$ prime rate - taxa de juros média praticada pelos trinta maiores bancos comerciais norte-americanos -, que se situava em $6,25 \%$ ao final de 1976 , havia saltado para $21,5 \%$ ao final de 1980 , primeiro ano do governo Reagan.
} 
de importações - que, conforme visto acima, comportavam aspectos sistêmicos, estruturais e que se relacionavam com os fundamentos pouco dinâmicos da economia brasileira - estariam então reunidos, sendo praticamente impossível ao regime, nesse contexto, manter o apelo desenvolvimentista que caracterizou o período de crescimento dos anos de 1970. Com isso, esvaneciam-se também as escassas bases de legitimidade econômica do ciclo militar brasileiro.

\section{0 marco político, econômico e institucional da Constituinte (1986-1988)}

A campanha de Tancredo Neves no Colégio Eleitoral, que o guindaria à Presidência da República em janeiro de 1985, vinha imbuída da tripla vaga de esperança de fazer do Brasil uma democracia plena (em seus aspectos institucionais e normativos), de atenuar o impacto da crise econômica e de promover a justiça social num país assolado por desigualdades. A morte de Tancredo não arrefeceu essas esperanças, que viriam a ser renovadas com a decretação do Plano Cruzado, um ano após que José Sarney tomou posse da Presidência. Nessa linha de raciocínio que incorpora a esperança como um elemento determinante da transição, pode-se estabelecer um contínuo entre as causas internacionais da crise econômica brasileira, a vitória da Aliança Democrática no Colégio Eleitoral, o resultado das eleições de novembro de 1986, a convocação da ANC e a promulgação da nova Carta, em outubro de 1988.

Transcorrido um ano da posse de Sarney, as condições econômicas do país e os acordos políticos da transição fizeram com que se verificassem mais traços de continuidade do que de descontinuidade entre o período militar e o início da Nova República, não obstante o importante trabalho de remoção do "entulho autoritário" realizado nesse período, basicamente com a passagem à 
legalidade dos partidos de esquerda até então proscri$\operatorname{tos}^{25}$. Sem a legitimidade política de Tancredo e surpreendido à última hora com a Presidência, Sarney teve de conviver com todos os indicadores econômicos negativos herdados do período militar, sobretudo com o agravamento da inflação e do desemprego, e a consequente deterioração da situação social do país. A Nova República mostrar-se-ia tão inepta quanto o último governo militar para enfrentar as causas domésticas e internacionais da estagnação e da crise de Estado, que não arrefecia, apesar - e talvez até por conta - dos leilões de privatização do setor siderúrgico. O ciclo da substituição de importações simplesmente chegara ao fim e o Governo não dispunha nem de ideias nem de instrumentos para gerar um novo modelo ou uma nova estratégia de desenvolvimento $^{26}$. Seria legítimo indagar se o governo Sarney desejava efetivamente promover o desenvolvimento ou, muito 242 mais comodamente, optar por manter a estratificação dos privilégios da tecnoburocracia e do capital, ainda receosos do crescimento potencial das esquerdas com o fim do período militar. Também nesse sentido, pode-se afirmar que as continuidades ainda prevaleciam sobre as descontinuidades, no tocante às relações entre a Nova República e o período imediatamente anterior.

Com a continuidade do caos que se havia instalado na economia brasileira e que rapidamente consumia o combustível da esperança abastecido na Campanha Diretas Já e na vitória da Aliança Democrática no Colégio Eleitoral, iniciou-se a era dos planos rocambolescos para se debelar a

\footnotetext{
${ }^{25}$ A remoção do "entulho autoritário" começou, paradoxalmente, em pleno regime autoritário - já no Governo Geisel - com a suspensão parcial da censura à imprensa, a aprovação da Lei da Anistia e a suspensão dos Atos Institucionais.

${ }^{26}$ Uma importante novidade e exceção à ausência de uma estratégia nacional de desenvolvimento terá sido a criação do Ministério da Ciência e Tecnologia (MCT) e da escolha do peemedebista Renato Archer para chefiá-lo.
} 
estagflação, o principal entre eles sendo o Plano Cruzado, lançado em 28 de fevereiro de 1986. A característica básica de tais planos era atacar as causas imediatas da inflação, de modo a gerar efeitos impactantes e de curto prazo (quase sempre com propósitos eleitorais) e não enfrentar suas causas remotas ou subjacentes, entre as quais assomavam o patrimonialismo, a inelasticidade da oferta, os baixos índices de competitividade econômica e de produtividade do trabalho, o protecionismo e a escassa integração do Brasil aos eixos dinâmicos da economia internacional.

O Plano Cruzado gerou consequências econômicas imediatas e efêmeras, mas que trariam dividendos políticos duradouros e perenes. Com a inflação contida por decreto, passando a hibernar em cerca de 3\% ao mês, contra os insustentáveis $20 \%$ mensais de antes, os resultados em termos de popularidade de Sarney e do PMDB foram espetaculares. O impacto do Plano Cruzado nas eleições de 1986 foi marcante e decisivo. O partido elegeu todos os governadores do país, com a exceção de Sergipe, e montou uma bancada, juntamente com o PFL, de 378 deputados, que viriam a ser empossados como constituintes a partir de $1^{\circ}$ de fevereiro de 1987 e que correspondiam a quase $80 \%$ do total de 487 deputados eleitos. Passadas as eleições e instalada a ANC, a crise e o caos econômico voltariam à cena, com o governo Sarney vindo a decretar unilateralmente moratória junto ao sistema multilateral de crédito e ao Clube de Paris, menos de quatro semanas após o início dos trabalhos da $\mathrm{ANC}^{27}$.

\footnotetext{
${ }^{27}$ A política econômica improvisada do PMDB da década de 1980 viria a cobrar um alto preço nas primeiras eleições diretas para presidente, em 1989, com o partido e seu líder, o deputado Ulysses Guimarães - o "Senhor Diretas", baluarte da luta contra o regime de exceção, que viria a ser abandonado por seu próprio partido - sendo forçados a amargar desempenho pífio naquele pleito, que viria a ser conquistado por um outsider.
} 
O fato, porém, de o PMDB ser uma grande frente política, alimentada por amplos setores sociais descontentes ou opositores do regime militar - que o situou como polo oposicionista num sistema bipartidário de fato (mesmo durante a segunda metade da década de 1980, após a reforma partidária de 1979, com a divisão entre os "autênticos" e o "partido do Sarney") -, traria consequências inesperadas para o desdobramento dos trabalhos constituintes. Se muitos, como o próprio Sarney e diversos parlamentares que mais tarde viriam a conspirar contra o regimento da $\mathrm{ANC}$, a partir da formação do "Centrão", representavam, em vários aspectos, o continuísmo em relação ao regime anterior, houve tantos outros que propugnavam por mudanças mais radicais na estrutura política, econômica e social do país, por um efetivo rompimento com o passado e por uma integração do Brasil aos eixos dinâmicos da economia mundial. Por circunstâncias que 244 foram esmiuçadas em outros trabalhos ${ }^{28}$, os progressistas acabaram por assumir posições estratégicas nas comissões e subcomissões da ANC, influindo nos resultados do processo e tendo um peso decisivo na aprovação final da Carta - o que mesmo a reação conservadora do Centrão não foi capaz de evitar.

Cabe avaliar, porém, ainda que superficialmente, quais seriam as relações mais diretas entre o contexto internacional da segunda metade dos anos de 1980 e os trabalhos da ANC, inclusive no que concerne ao resultado final da ação dos progressistas, este considerado desproporcionalmente favorável quando se tem em vista a real dimensão de sua bancada.

Em termos metodológicos, não se trata do estabelecimento de diretas relações causais entre acontecimentos internacionais e decisões políticas domésticas, da forma,

\footnotetext{
${ }^{28}$ Ver Pilatti (2008), por exemplo.
} 
por exemplo, como as pressões das ONGs internacionais suscitaram uma mudança drástica (para melhor) da política brasileira de direitos humanos no começo dos anos de 1990. Trata-se de mudanças estruturais do cenário internacional que, ainda que tenham tido impacto apenas indireto tanto na política e na economia brasileiras quanto nos debates políticos que transcorriam ao tempo da Constituinte, nem por isso foram menos profundas ou marcantes, na perspectiva holística e sistêmica a que este texto se filia. Em termos um tanto gerais, além de situar-se num momento crucial da crise de Estado brasileira, a Constituinte começava a sofrer os influxos da universalização de valores trazida à baila pela globalização política e pela formação de um "sistema-mundo" articulado a partir de "sociedades em rede" (Castells, 1996, p. 469).

No plano econômico, a Constituinte foi promulgada num momento histórico de transição, entre o fim do período de SI e o advento da ampla liberalização capitaneada, na América Latina, pelo Consenso de Washington ${ }^{29}$. Os trabalhos em plenário ocorreram em momento de certa dúvida e hesitação, sobretudo de parte das esquerdas, em relação às plataformas que pretenderiam adotar, diante dos acontecimentos internacionais que prenunciavam o fim do socialismo-regime - de modo radical e dramático, no caso da extinta URSS, e de modo mais gradual, no caso da China -, do intervencionismo econômico estatal e das ideologias de corte mais universalizante, como o próprio

\footnotetext{
${ }^{29}$ Foi ainda promulgada na transição entre um modelo de dirigismo excessivo (consubstanciado, por exemplo, no tabelamento constitucional da taxa de juros) e outro de abertura econômica (instalado pouco mais de um ano a seguir) com o advento das novas políticas industrial e de comércio exterior do governo Collor. Para uma análise da política externa do governo Collor, ver Cruz Júnior et al. (1993). No plano internacional, a referência ao dirigismo econômico relaciona-se ao desmantelamento da antiga União Soviética, ao fim do bloco socialista europeu e ao consequënte advento das economias de mercado nesses países.
} 
comunismo soviético ou algumas experiências autogestionárias do Leste Europeu ${ }^{30}$.

O amadurecimento das posições da esquerda durante a Constituinte, no sentido de abandonar as referências ao socialismo das "Internacionais", romper definitivamente com o estalinismo e passar a apoiar as reformas democratizantes e, até certo ponto, liberalizantes do então premiê soviético Mikhail Gorbachev, tiveram ainda dois pontos emblemáticos no Brasil, que ganharam força principalmente após o triunfo conservador nas eleições de 1989. No primeiro caso, o deputado Federal José Genoíno, um dos ícones da esquerda brasileira da década de 1980, anunciou seu abandono do comunismo e do marxismo, proclamando-se como "não ortodoxo" e admitindo o lucro, o capitalismo e as relações descentralizadas de produção como instrumentos mais eficientes para o desenvolvimento e a geração de bem-estar social (Folha de S. Paulo, 1991b, 246 p. 12); o segundo caso pode ser localizado antes mesmo da instalação da ANC, em pleno desenrolar do programa de reformas na antiga URSS, em que o ex-secretário-geral do PT, Francisco Weffort, afirmava que "hoje, no Brasil, o sonho da revolução coincide com a luta pela democracia" (Jornal do Brasil, 1985, p. 14). Mais tarde, ao regressar de ano sabático no Helen Kellogg Institute of International Studies da Universidade de Notre Dame, Weffort instilaria grande controvérsia no debate político brasileiro ao declarar, em entrevista à Folha de S. Paulo - na mesma linha da

\footnotetext{
${ }^{30}$ Havia diversas manifestações de dúvida, mesmo durante o processo constituinte, em relação aos novos rumos da esquerda, com o fim do bipolarismo e da Guerra Fria. No caso do PT, tais dúvidas foram refletidas num grande seminário realizado pouco depois pelo partido, em abril de 1989, que resultou na publicação Weffort (1989). Conferir especialmente Carvalho (1989). No caso do antigo PCB (hoje Partido Popular Socialista/PPS), a resolução política do seu diretório nacional, de primeiro de setembro de 1989, conclamava os militantes para o Congresso que iria criar uma "nova formação política" e reconhecia a dificuldade da tarefa que teria pela frente de "[...] buscar uma nova síntese teórica, democrática e humanista, que fundamente um novo socialismo" (PCB, 1991, p. 2).
} 
anteriormente concedida por José Genoíno (Folha de S. Paulo, 1991b, p. 12) - que o socialismo-regime nada mais teria a oferecer ao Brasil ${ }^{31}$. Seria algo temerário conceber, a partir desses e diversos outros exemplos, que os acontecimentos internacionais que precipitariam o final da Guerra Fria não teriam impacto nos trabalhos da Constituinte e no quadro político brasileiro mais amplo do final dos anos 1980, especialmente nas eleições presidenciais de 1989.

Uma questão política de fundo a se ressaltar no âmbito dos trabalhos da Constituinte é a consciência de que influente segmento das esquerdas e, mais importante do que isso, as teses centrais que elas defendiam (alusivas, por exemplo, à democratização e à cultura democrática, à promoção de justiça e de inclusão social e à integração e interdependência entre as nações no plano internacional) ganhavam terreno em momentos obscuros da transição, em que houve tentativas de fraudes nas eleições de 1982, a rejeição da Emenda Constitucional das eleições diretas, em abril de 1984, e a invasão militar da Companhia Siderúrgica Nacional, em novembro de 1988. Esse argumento é tanto mais importante se concordamos com Florestan Fernandes - e na linha do argumento exposto anteriormente - que a Nova República não representou ruptura de fato com o regime militar ${ }^{32}$. Conforme o ângulo de análise a que se queira dar preferência, a democracia plena ter-se-á con-

\footnotetext{
${ }^{31}$ Cito de memória essa declaração de Weffort, proferida após seu regresso dos EUA, embora, em textos subsequentes, ele tenha deixado claro sua desaprovação ao socialismo-regime como alternativa política para a América Latina e o Brasil. Em artigo de 1994, por exemplo, asseverava que "[...] não deveria surpreender a ninguém que os socialistas, dada sua atual carência de alternativas econômicas e de uma teoria social, devam abraçar nos próximos anos uma concepção do socialismo que não seja necessariamente vinculada a um sistema em particular, mas definida, sobretudo, em termos de determinados valores" (Weffort, 1994, p.403). 32 "[As classes dirigentes] [...] usaram o Colégio Eleitoral como uma cidadela política, através do qual 'elegeu' os governantes da 'nova' República e deu continuidade à palavra de ordem da ditadura: 'transição lenta, gradual e segura'" (Fernandes, 1989, p. 153).
} 
solidado com a posse do primeiro presidente diretamente eleito após 1964 ou ainda somente depois, com a primeira vitória da oposição em eleições presidenciais no Brasil, em 2002. De toda forma, a Constituinte representa o ponto culminante da transição no Brasil e de uma vaga democratizante que havia arrastado praticamente todas as antigas ditaduras da América Latina, correspondendo ao mesmo tempo à primazia de uma tese sustentada pela maior parte da esquerda e do campo progressista. A Constituinte e a conclusão do processo de abertura política não corresponderiam, em absoluto - conforme preconizava o pensamento conservador até bem pouco antes - um avanço do pensamento extremista de esquerda, em qualquer de suas vertentes, e isso devia ser atribuído, em grande medida, a um novo contexto internacional marcado por mais democracia, pluralismo e tolerância.

O âmbito negociador da Constituinte esteve, portanto, 248 associado a um cenário internacional marcado por novos valores e princípios que deixaram suas marcas no próprio processo político brasileiro, como anteriormente se indicou de forma mais geral. O contexto político da segunda metade da década de 1980 é profundamente influenciado pelas transformações radicais na ex-URSS, pelas políticas de abertura, transparência e aceleração econômica empreendidas pelo então premier Gorbachev. A distensão da ex-URSS com os EUA havia chegado ao ápice com o acordo que previra a retirada, por ambas as partes, de todos os mísseis estratégicos da Europa, assinado durante visita de Gorbachev a Washington, em dezembro de 1987, e ratificado na visita de Reagan a Moscou, em junho de 1988. Momento dramático da abertura patrocinada por Gorbachev foi quando telefonou pessoalmente para o físico e dissidente Andrei Sakharov, pouco antes da visita de Reagan a Moscou, para anunciar que o exílio seu e da mulher Elena havia acabado, com um pedido formal de desculpas. $\mathrm{O}$ 
casal foi então convidado a participar do jantar de gala em homenagem a Reagan no Kremlin (Veja, 1988, p. 53).

Outro importante acontecimento que atraía a atenção internacional no período dos trabalhos constituintes no Brasil foi a decisão do Conselho Europeu de promover a plena integração econômica, monetária, comercial, educacional, de trânsito de pessoas, serviços e mercadorias no espaço comunitário, a partir de 1992. Tal medida apresentava um componente marcadamente ético e político, muito além da dimensão econômico-comercial, diante do fato de a integração ter sido anunciada para um continente rasgado por guerras que vitimaram dezenas de milhões de pessoas em passado não muito distante. Tal decisão ajudava a compor um zeitgeist da segunda metade dos anos de 1980, substancialmente distinto do que prevalecia menos de dez anos antes, no quadro geral das relações internacionais e do sistema internacional da Guerra Fria ${ }^{33}$.

As características do novo sistema internacional decorrentes do iminente fim da Guerra Fria produziriam forte impacto, na perspectiva metodológica aqui adotada, nos trabalhos dos constituintes. O temperamento geral prevalecente foi de diálogo e composição, a partir do descrédito das doutrinas extremistas e universalizantes e com a primazia de valores que seriam consubstanciados por John Rawls no conceito de "fato do pluralismo" (Rawls, 1996, pp. 36-7). Segundo esse conceito, os meios e as regras, a "primazia do direito sobre o princípio" (right over the good) devem prevalecer lógica e racionalmente sobre ideais de corte finalístico. A Constituinte tornava-se, desse modo, a suprema regra do

\footnotetext{
${ }^{33}$ Um tanto sintomaticamente, o parágrafo único do artigo $4^{\circ}$ da Constituição de 1988 preconiza que o Brasil "buscará a integração econômica, política, social e cultural dos povos da América Latina, visando à formação de uma comunidade latino-americana de nações", ideal que, em certa medida, remonta ao período da "política externa independente" dos anos de 1960 e exprime valores cosmopolitas e internacionalistas.
} 
jogo pela qual toda atividade política e as relações sociais do país teriam de se pautar. Tentativas de desqualificação do processo constituinte, empreendidas, sobretudo, pelo Palácio do Planalto e pelo ministro do Exército, não foram tomadas a sério nem pela sociedade brasileira, nem pelos próprios constituintes, na figura do presidente da ANC, Ulysses Guimarães. No plano internacional, as grandes, crescentes e até então improváveis afinidades pessoais entre Reagan e Gorbachev indicavam os contornos do novo sistema internacional, no qual o confronto e os extremismos cediam o passo ao diálogo e à composição.

A substituição da "doutrina da contenção" da Guerra Fria pelo "princípio da reciprocidade" (Rawls, 1996, pp.16, 49-50) do novo sistema internacional teve reflexos explícitos na Constituinte e na nova Constituição. Isso fica claro quando se comparam os dispositivos do artigo 7ํ da Emenda Constitucional n.1, de outubro de 1969 (que mencionava 250 "conflitos internacionais" e "guerra de conquista") com o artigo $4^{\circ}$ da Constituição de 1988, que elenca um rol de princípios éticos que devem reger a política externa brasileira e as relações internacionais. Entre estes se encontram o aludido princípio da integração latino-americana (como emulação da tendência geral de integração política, comercial e econômica em diversas regiões do planeta); a ideia da "cooperação entre os povos para o progresso da humanidade" (em contraste com a divisão do mundo em esferas de influência durante a Guerra Fria e com a existência de ideologias extremistas e degeneradas como o nazismo, o fascismo, o estalinismo, o maoísmo, o franquismo, o macartismo etc.); o primado do multilateralismo e do direito internacional em relação ao isolacionismo e o unilateralismo da fase anterior; o multipolarismo e a emergência de novos atores internacionais, em relação ao sistema bipolar anterior; a prevalência de valores éticos como o respeito aos direitos humanos e ao meio ambiente em relação à antiga 
supremacia da soberania territorial ${ }^{34} \mathrm{e}$, por fim, a ampliação da agenda internacional, também a partir dos anos de 1980, com a inauguração da "era das conferências sociais" das Nações Unidas, com o objetivo de tratar multilateralmente temas até então restritos à competência interna dos países (meio ambiente, direitos humanos, saúde, combate à pobreza, promoção do desenvolvimento sustentável, qualidade de vida nas metrópoles, direitos e saúde das mulheres e crianças, combate à xenofobia, racismo e todas as formas de discriminação, entre muitas outras). A adequação do Brasil a esses novos valores internacionais foi a mais natural possível, com a Constituinte e o artigo $4^{\circ}$ da Constituição tendo sido amplamente responsáveis por essa plena e rápida inserção política brasileira no cenário internacional, com reflexos positivos visíveis que se prolongam nos dias atuais ${ }^{35}$.

\section{O voo da borboleta e a Constituição do país governável}

Na introdução de sua portentosa obra sobre Lukács, Ortega y Gasset e Heidegger, Francisco Gil Villegas (1996, p. 13) questionava, um tanto sardonicamente, se "por acaso não é uma das características típicas do bizantinismo hermenêutico começar a procurar semelhanças onde as divergências se presentam tão grandes e evidentes?". Da mesma forma, seria um exercício de "bizantinismo hermenêutico" buscar causas internacionais remotas para fenômenos que, muitas vezes, teriam raízes ali mesmo na esquina do tempo e da história? Como alguns exemplos possíveis, bastaria atinar para a mobilização e a apresentação de emendas populares para a Constituinte, as greves, a reação de militares, camponeses

\footnotetext{
${ }^{34}$ O fim do regime do Apartheid na África do Sul em 1994 e a prisão do ex-ditador chileno Augusto Pinochet em Londres, entre 1998 e 2000, exprimem a primazia dos direitos humanos no sistema internacional e a relativização do conceito de soberania, tal como expresso nas formulações clássicas de Jean Bodin e Hobbes.

${ }^{35}$ Estudo pioneiro sobre o impacto potencial dos novos dispositivos da Constituição de 1988 sobre a política externa brasileira é o de Almeida (1990).
} 
e ruralistas durante aquele processo para perceber como determinadas ações e resultados na Constituinte dispunham de causas mais imediatas e perfeitamente discerníveis no tempo e no espaço - no caso, a agenda político-social brasileira da politicamente movimentada e economicamente estagnada década de 1980.

Num outro diapasão, a busca de causas internacionais para os processos políticos domésticos brasileiros poderia radicar mais prosaicamente na teoria do caos do matemático norte-americano Edward Lorenz, que recorreu ao voo de uma borboleta no Brasil para explicar a formação de tornados no Texas (Lorenz, 1972). Nessa teoria, os fenômenos sociais estariam tão intimamente interconectados em escala global que a tese do impacto das relações internacionais nos trabalhos da Constituinte soaria, mais que bizantina, trivial.

$O$ fato é que, entre os extremos da trivialidade e do bizantinismo, há um meio termo, capturado por Raymundo 252 Faoro na afirmação citada no início deste artigo, que introduz causas internacionais diretas e indiretas em diversos episódios históricos e movimentos político-sociais brasileiros. Até, grosso modo, o advento do Plano de Metas de Juscelino Kubitschek, a economia e a sociedade brasileiras eram fortemente tributárias desses influxos forâneos: Gilberto Freyre ensinou sobre a presença decisiva e marcante dos ingleses na cultura e na sociedade brasileiras do século XIX e primeiras décadas do século XX; a literatura e a cultura brasileiras da década de 1920 em diante dependeram fortemente das vanguardas artísticas europeias; o mesmo ocorrendo com a organização institucional militar, universitária, acadêmica e educacional do Brasil nas primeiras décadas do século XX. O advento da República foi inspirado em ideais e instituições adotados nos $\mathrm{EUA}^{36}$.

\footnotetext{
${ }^{36}$ Tal como o foi, muito mais recentemente, a fixação do mandato presidencial em quatro anos, com a possibilidade de uma reeleição sucessiva.
} 
O contexto da Constituinte foi marcado, contudo, por um duplo movimento social: por um lado, o Brasil havia se tornado mais maduro e socialmente independente para refletir e agir de maneira autônoma em relação ao seu lugar no mundo ${ }^{37}$; de outro, o fenômeno da globalização apenas iniciava sua escalada vertiginosa rumo à homogeneização de políticas macroeconômicas e de bem-estar social em escala global. Se hoje verificamos que as políticas macroeconômicas de todos os países do mundo, particularmente os da América Latina, são muito similares entre si, em 1987-1988 não havia clareza sobre os rumos a seguir, sobre o peso de determinadas trajetórias econômicas de dependência e de especialização produtiva, e sobre as opções políticas que se descortinariam para os movimentos populares que, de uma hora para outra, ficaram sem referências políticas óbvias no cenário internacional.

Justamente por essa condição histórica peculiar, de limiar entre duas eras e de estar situada na transição de um sistema internacional para outro, a Constituinte e a Constituição de 1988 buscavam observar atentamente o que se passava no mundo, com vistas a capturar os princípios, valores e tendências políticas que se firmariam nos anos e décadas a seguir. Por observar atentamente esse cenário internacional, por antever seus limites e possibilidades, a Constituição de 1988 não deixou o país ingovernável, conforme ressoavam alguns maus augúrios palacianos da época. Ainda que tenha tido de se emendar por mais de quatro dúzias de vezes, a maioria dessas alterações visava corrigir resquícios da era da substituição de importações e do dirigismo estatal num modelo econômico global marcado pela ação desimpedida dos mercados - com reflexos muitas vezes catastróficos, conforme se pôde verificar em oportunidades recentes -, particularmente financeiros e

\footnotetext{
${ }^{37}$ A tese de doutorado de Maria Regina Soares de Lima (1986) situa os primeiros momentos de maior autonomia da política externa brasileira, em relação ao conflito bipolar, durante os anos de 1970.
} 
oligopolizados. Por saber fazer a leitura correta e seletiva das pressões estruturais de um cenário internacional complexo e que se transformava com grande velocidade, a Constituição de 1988 não só tornou o país plenamente governável, mas estabeleceu os parâmetros da legitimidade democrática brasileira pelos tempos a seguir. Houve inúmeros desafios, e a Constituição saiu-se bem em todos, de modo geral.

\section{Ademar Seabra da Cruz Júnior.}

é professor do Instituto Rio Branco (IRBr/Brasília) e pesquisador do Cedec.

\section{Referências bibliográficas}

ABREU, M. P. 2002. "Política comercial brasileira: limites e oportunidades". In: PINHEIRO, A et al. (orgs.) O desafio das exportações brasileiras. Rio de Janeiro: BNDES, pp. 27-49.

ALMEIDA, P. R. 1990. "A estrutura constitucional das relações internacionais e o sistema político brasileiro". Contexto Internacional, ano 6, v.12,

2002. Diplomacia financeira: o Brasil e o FMI, de 1944 a 2002. Disponível em www.pralmeida.org/04Temas/11academia/05materiais/927 DiploFinanceira.html. Acesso em 28/02/2013.

BAHRO, R. 1980. A alternativa: para uma crítica do socialismo real. Rio de Janeiro: Paz e Terra.

CARVALHO, C. E. 1989. "Dívida interna e sistema bancário". In: WEFFORT, F. (org.). PT: um projeto para o Brasil. São Paulo: Brasiliense, pp. 93-124.

CARVALHO, V. R.; LIMA, G. T. 2007. "A restrição externa e a perda de dinamismo da economia brasileira: a relação entre estrutura produtiva e crescimento econômico". Disponível em <www.anpec.org.br/encontro2007/artigos/A07A013.pdf>. Acesso em 28/02/2013.

CASTELLS, M. 1996. The rise of network society: The information age: economy, society and culture. Malden: Blackwell, v. 1.

CHANG, H.-J. 2003. Chutando a escada: a estratégia do desenvolvimento em perspectiva. São Paulo: Ed. da Unesp.

CHANG, J.; HALLIDAY, J. 2007. Mao: the unknown story. London: Vintage.

CRUZ JÚNIOR et al. 1993. "Brazil's foreign policy under Collor". Journal of Interamerican Studies and World Affairs, v.35, n.1., pp. 119-44. 
DRUCKER, P. 1986. “The changed world economy”. Foreign Affairs, v.64, n. 4, pp. 768-91.

DURKHEIM, E. 1987. "Fatos sociais". In: As regras do método sociológico. São Paulo: Companhia Editora Nacional.

FAORO, R. 1976. "Romance sem heróis". Veja, 28 de abr., p.4.

FERNANDES, F. 1989. Pensamento e ação: o PT e os rumos do socialismo. São Paulo: Brasiliense.

FOLHA DE SÃO PAULO. 1991a. 20 textos que fizeram história. São Paulo: Folha de São Paulo.

1991b. "O ex-guerrilheiro Genoino abandona o marxismo", ano 71, n. 22.624, 13 de março, p. 12.

FURTADO, C. 1992. Brasil: a construção interrompida. Rio de Janeiro/São Paulo: Paz e Terra.

GASPARI, E. 2004. A ditadura encurralada. São Paulo: Cia. das Letras.

GORBACHEV, M. 1988. Perestroika: novas ideias para o meu país e o mundo. São Paulo: Best Seller.

GUATTARI, F. 1982. Lula: entrevista a Felix Guattari. São Paulo: Brasiliense. HIBBS, D. 1977, "Political parties and macroeconomic policy". The American Political Science Review, v. 71, n. 4, pp. 1467-87.

JORNAL DO BRASIL. 1977. "Deputado vê na saída de Frota a 'gota d'água'”. Disponível em www.arqanalagoa.ufscar.br/pdf/recortes/ R04203.pdf.

1985. "O sonho agora é a democracia”, ano 95, n. 237, $1^{\circ}$ dez., p. 14 (Caderno B Especial).

KENNEDY, P. 1993. Preparing for the twenty-first century. New York: Random House.

LAPALOMBARA, J. 1966. "The transformation of the west European party systems”. In: _ _ WEINER, M. (orgs.). Political parties and political development. Princeton: PUP, pp. 177-200.

LIMA, M. R. S. 1986. The political economy of Brazilian foreign policy: nuclear energy, trade and Itaipu. Nashville, 443p. Tese de doutorado. Departamento de ciências sociais da Universidade de Vanderbilt.

LORENZ, E. 1972. "Predictability: does the flap of a butterfly's wings in Brazil set off a tornado in Texas?". Paper apresentado no 139th Annual Meeting of American Association for the Advancement of Science. Boston, $29 \mathrm{de} \mathrm{dez.}$

NADER, A. B. 1998. Autênticos do MDB: semeadores da democracia. São Paulo: Paz e Terra.

O GLOBO. 2012. "Crise abalou soberania brasileira". Disponível em oglobo.globo.com/economia/crise-abalou-soberania-brasileira-5976897. Acesso em 28/03/2012. 
PARTIDO COMUNISTA BRASILEIRO. 1991. "Resolução política do diretório nacional do PCB”. Brasília [mimeo].

PILATTI, A. 2008. A constituinte de 1987-1988: progressistas, conservadores, ordem econômica e regras do jogo. Rio de Janeiro: Lumen Juris.

PRADO JÚNIOR, C. 1966. A revolução brasileira. São Paulo: Brasiliense.

RAWLS, J. 1996. Political liberalism. New York: Columbia University Press.

SALLUM JÚNIOR, B. 1996. Labirintos: dos generais à nova república. São Paulo: Hucitec.

SAUS, J. et al. 2007. "Un caso exitoso de negociación diplomática: el reconocimiento de la república popular China”. Disponível em www.ort. edu.uy/facs/pdf/documentodetrabajo34.pdf. Acesso em 28/02/2013.

SAUSSURE, F. 1972. Curso de linguística general. Madrid: Alianza Editorial.

SILVA, H. C. M. 2004. Da substituição de importações à substituição de exportações. Porto Alegre: Ed. da UFRGS.

SKIDMORE, T. 1988. Brasil: de Castelo a Tancredo. Rio de Janeiro/São Paulo: Paz e Terra.

SUTZ, J. 2000. "The university-industry-government relations in Latin America”. Research Policy, n. 29, pp. 279-90.

VEJA. 1976. “À espera dos frutos”, n. 401. 12 mai., pp. 16-23. 1982. “Os 100 dias negros”, n. 745, 15 dez., p. 142-7. 1988. “Caça ao dragão em Moscou”, n. 1031, 8 jun., p. 50-6.

VILLEGAS, F. G. 1996. Los profetas y el mesías: Lukács y Ortega como precursores de Heidegger en el Zeitgeist de la modernidad (1900-1929). México: Fondo de Cultura Económico.

WEFFORT, F. (org.). 1989. PT: um projeto para o Brasil. São Paulo: Brasiliense. 1994. "El Futuro del Socialismo". Revista de Estudios Públicos, v. 54, pp. 395-407.

WILCZYNSKI, J. 1972. The economics of socialism. London: Allen \& Unwin. 